\title{
Oral Corrective Feedback: Investigating Kurdish High School Teachers' Beliefs and Practices
}

\author{
Yaseen Alzeebaree $^{1}$, Hussein Ali Ahmed ${ }^{1} \&$ Idrees Ali Hasan ${ }^{1,2}$ \\ ${ }^{1}$ Nawroz University, College of Languages, Department of English, Iraq \\ ${ }^{2}$ Duhok Polytechnic University, Iraq \\ Correspondence: Yaseen Alzeebaree, College of Languages, Department of English, Iraq. E-mail: \\ Yassin.teacher@gmail.com
}

Received: June 15, 2018 Accepted: July 6, 2018 Online Published: July 28, 2018

doi:10.5539/ijel.v8n6p115 URL: https://doi.org/10.5539/ijel.v8n6p115

\begin{abstract}
The current research explores the relationship between the beliefs and the actual classroom practices of the Kurdish teachers of English as a foreign language (EFL) regarding oral corrective feedback (OCF). To collect the data required, a questionnaire was administered to 8 Kurdish teachers of EFL of different academic qualifications from three different schools, and likewise a 5-hour audio-recorded classroom observation was carried out with the same sample. The findings revealed that almost all teachers' beliefs were identical with their actual practices with regard to who should provide OCF. In contrast, there was a discrepancy between their stated beliefs and practices in classroom regarding the timing of OCF, how to provide OCF and which types of errors to correct. The teachers highlighted the importance and the effectiveness of providing corrective feedback in EFL settings.
\end{abstract}

Keywords: Oral corrective feedback; practice and beliefs; Kurdish teachers of EFL

\section{Introduction}

The growing interest in learning English in most developing countries imposes upon teachers the utilization of various techniques and strategies so as to meet learners' linguistic and educational needs. Iraqi Kurdistan Region, where EFL has gained prominence for more than a decade, is no exception. The numbers of students enrolled in both governmental and nongovernmental colleges and institutes are increasing. Such a tendency to learn English is due to a number of reasons the most important of which is getting the proficiency certificate in English language as it forms a basic prerequisite of joining the postgraduate studies in Iraqi Kurdistan Universities (Alzeebaree, 2017) and of getting a job especially with the international organizations that take from Iraqi Kurdistan Region as a safe site to offer their services in the Region and Iraq at large. Finally, travelling abroad, either for short-term purposes or for good, is behind learning EFL as well.

This study endeavours to shed light on the problem of when, how to provide corrective feedback (CF) in instructional settings and who (teacher or learners) should correct the errors as there is no consensus over the provision of remedies for such problems, Verbal interaction has gained more attention and importance between students and teachers or among students themselves in educational settings particularly after emerging communicative approaches to language teaching. Therefore, the role and effectiveness of OCF in classroom have been reflected. Krashen (1982, p. 74) claimed that correcting error is 'a serious mistake' since it may cause a reluctance to communicate and it does not develop the acquired knowledge (Ellis, 2009). This is in contrast with that of (Gass, 1997) who argues that corrective feedback helps learners to differentiate between the second language they produce and target forms. Though relevant empirical studies confirm the positive role of OCF in developing foreign language learning (FLL), its effects may be constrained by contextual aspects and individual learner differences (Li, 2010; Lyster \& Saito, 2010). OCF is also viewed positively, i.e. correct or acceptable since it, as (Gass, 1997) argues, helps learners to differentiate between the new language they produce and target forms. The same opposing parties, as Ellis (2009) argues, have also split over the timing of OCF. Should it be given immediately? Or should be delayed?

The present research addresses the following research questions

1) What are Kurdish EFL teachers' perception concerning: 
a) Who to give OCF,

b) When to give OCF,

c) How to give OCF, and

d) What types of errors to correct

2) What are the classroom practices carried out by Kurdish EFL teachers regarding (a), (c) and (c) above?

3) Is there matching between EFL teachers' beliefs and practices?

4) The present study hypothesized that there is inconsistency between the Kurdish EFL teachers' beliefs and classroom practices concerning:

a) Who should provide $\mathrm{OCF}$,

b) The timing of OCF,

c) The type of OCF provided, and

d) The types of errors to correct.

This study aims at identifying the beliefs of EFL Kurdish teachers concerning the provision of OCF and comparing such beliefs to the actual use of OCF in EFL classrooms. The value of the current research lies in the fact that through OCF and the verbal interaction it entails have gained more attention and importance among both students and teachers in the educational settings especially after the emergence and use of the communicative approaches to language teaching. The model adopted in the current research is that of Lyster and Ranta (1997) and used as the framework for categorizing types of corrective feedback.

\subsection{Corrective Feedback}

Committing errors is negatively viewed in all cultures. Errors committed on performing various learning tasks are not favoured as they outline a drawback in performing such tasks. Correction is defined as "the replacement of error or mistake by what is correct" (Schegloff et al., 1977, p. 363). It is, according to Lightbown and Spada (1990), "any indication to the learners that their use of the target language is incorrect". As for feedback, according to (Hattie \& Timperley, 2007), feedback refers to the provision of information on one's performance by a teacher or a peer. Saville-Troike (2007) defines feedback as a type of interaction that can boost L2 acquisition by showing learners where they go wrong and providing them with correct required alternatives. Similarly, Ellis (2009) argues that feedback, based on the behavioristic and communicative approaches to language teaching, is a way of enhancing learners' motivation and linguistic accuracy. In their study, Voerman, Meijer, Korthagen, and Simons (2012) and Voerman et al. (2012) indicate that feedback means providing learners with performance-based information, with the aim to improve learning. Concerning corrective feedback (CF), any information from any source concerning what learners perform to stimulate L2 acquisition is defined as corrective feedback (CF) (Cornillie, Clarebout, \& Desmet, 2012). CF is also defined as an utterance provided by a teacher and/or a peer on L2 learners' erroneous performance (Li, 2014). Furthermore, Nassaji and Kartchava (2017) define CF as any information whether oral or written that highlights learners' erroneous utterances. Dealing with errors and resorting to CF in L2 teaching are undoubtedly of vital importance to both FL teachers and learners, yet there has been much controversy and hot debates as there have been conflicting outcomes obtained in this respect (Hyland, 1990). According to (Long, 2006), CF is a provision of either negative or positive evidence, both of which refer to an utterance provided about what is or what is not accepted in the FL.

\subsection{Types of Corrective Feedback}

In terms of the types of OCF, Lyster and Ranta (1997) identify six kinds of feedback provided by EFL teachers to their students during communicative interaction. Here, teachers react to students' phonological, lexical and grammatical erroneous utterances using explicit correction, recast, clarification requests, metalinguistic feedback, elicitation and repetition. 
Table 1. Types of OCF

\begin{tabular}{|c|c|c|c|}
\hline & Types of CF & Definition & Examples (Lee, 2013) \\
\hline 1 & $\begin{array}{l}\text { Explicit } \\
\text { correction }\end{array}$ & $\begin{array}{l}\text { Indicates an error has been committed, identifies the error, and provides } \\
\text { the correction }\end{array}$ & $\begin{array}{l}\text { S: On May } \\
\text { T: Not on May, In May } \\
\quad \text { We say, 'It will start in May'. } \\
\text { S: Are there some people in the garden? } \\
\text { T: Are there any people? Ok. We use 'any' in } \\
\text { plural questions }\end{array}$ \\
\hline 2 & Recast & $\begin{array}{l}\text { Reformulates all or part of the incorrect word or phrase, to show the } \\
\text { correct form without explicitly identifying the error }\end{array}$ & $\begin{array}{l}\text { S: I have to find the answer on the book? } \\
\text { T: In the book }\end{array}$ \\
\hline 3 & $\begin{array}{l}\text { Clarification } \\
\text { request }\end{array}$ & $\begin{array}{l}\text { Indicates that the student's utterance was not understood and asks the } \\
\text { student to reformulate it }\end{array}$ & $\begin{array}{l}\text { S: What do you spend with your wife? } \\
\text { T: What? (Or, Sorry?) }\end{array}$ \\
\hline 4 & $\begin{array}{l}\text { Meta-linguistic } \\
\text { feedback }\end{array}$ & $\begin{array}{l}\text { Gives technical linguistic information about the error without explicitly } \\
\text { providing the correct answer }\end{array}$ & $\begin{array}{l}\text { S: There are influence person who } \\
\text { T: Influence is a noun }\end{array}$ \\
\hline 5 & Elicitation & $\begin{array}{l}\text { Prompts the student to self-correct by pausing so the student can fill in } \\
\text { the correct word or phrase }\end{array}$ & $\begin{array}{l}\text { S: This tea is very warm } \\
\text { T: It's very? } \\
\text { S: Hot }\end{array}$ \\
\hline 6 & Repetition & $\begin{array}{l}\text { Repeats the student's error while highlighting the error or mistake by } \\
\text { means of emphatic stress }\end{array}$ & $\begin{array}{l}\text { S: I will showed you } \\
\text { T: I will SHOWED you? } \\
\text { S: I'll show you }\end{array}$ \\
\hline
\end{tabular}

\subsection{Corrective Feedback Techniques}

In an earlier study, Fang (1996) suggests that behavior is strongly influenced by beliefs. Similarly, in language teaching, there is a strong relationship between classroom practices and cognition of L2 teachers (Borg, 2009) and beliefs play and make the claim (Pajares, 1992).

Providing OCF with regard to L2 performance has gained much interest, importance, and attention by teachers of L2s and researchers carrying out researches in the domain of L2 acquisition (Ellis, 2010; Roy Lyster, 2015).

Concerning the way to correct errors; i.e. "how", errors are corrected either explicitly (directly) or implicitly (indirectly). The former indicates the provision of the correct form to the students by the teacher, and it is desirable for low-level learners who are unable to self-correct (Ellis, 2009). While the latter outline's a teacher's indication that an error exists but no provision of CF, thus leaving it to the student to find it (Lalande, 1982). Different studies have examined the difference between direct and indirect CF and the effectiveness of each technique. Lalande (1982) and Ferris and Helt (2000) indicate that indirect feedback is indeed more effective in enabling students to correct their errors. This is just contrary to the outcomes of a study conducted by (Chandler, 2003) which suggests that direct feedback is better, at the time Robb et al. (1986) and Frantzen (1995) have found no differences between direct and indirect $\mathrm{CF}$.

As for the timing to provide $\mathrm{CF}$, it is noteworthy that $\mathrm{CF}$ is provided either immediately after an error is made or is delayed to the end of conversation. The foregoing statement is based on the fact that EFL teachers are after the development of either fluency, expression of meaning or accuracy, well-formed correct structures by the learners. As such and as (Hernández Méndez, Cruz, \& del Rosario, 2012) point out, teachers who focus on meaning (fluency) in their EFL classes usually favor postponing the provision of CF until the conversation comes to an end, while those who focus on accuracy advocate both immediate or delayed provision of OCF.

\section{Method}

\subsection{Setting}

The study was carried out at three different state high schools in the city of Akre, Kurdistan region, Iraq during the first term of the academic year 2017-2018 where English is one of the basic and compulsory courses taught five times, each 40-minutes, per week.

\subsection{Participants}

The participants in this study were 8 EFL teachers ( 7 males and 1 female). They ranged in age from 24 to 42 years and with varying levels of experience in teaching English, 1-18 years, and of different academic qualifications. Convenience sampling was utilized by the researcher as the participants were selected on the basis of their availability. 


\subsection{Research Instrument}

Classroom observations were done to elicit the required data regarding the participants' OCF practices besides an open-ended questionnaire was administered to investigate participants' beliefs of OCF.

\subsection{Data Collection}

The data were collected during the first term of the academic year 2017-2018. Each participant was observed for about 40 minutes when field notes were taken and the classes were audio-recorded. As the observations were over, the participants were asked to fill in a questionnaire.

\subsection{Data analysis}

The present study investigates the relationship between teachers' beliefs and their actual classroom practices regarding the types of OCF. The data collected were analysed on the basis of Lyster and Ranta's taxonomy (1997), presented earlier, and according to Ellis (2009) and Varnosfadrani (2006) classification of feedback, namely 'immediate' OCF as the teacher stops the learner on the spot and corrects the error in the middle of conversation and/or 'delayed' OCF (correction after the learner's utterance). The OCF beliefs and practices of each participant are summarized in tables 2 below.

Table 2. Teachers' beliefs and practices on OCF

\begin{tabular}{|c|c|c|c|c|c|}
\hline & Participants & Who? & When? & How? & Type of Error \\
\hline \multirow[t]{2}{*}{1} & Teacher's Belief & Students & $\begin{array}{l}\text { Delayed } \\
\text { feedback }\end{array}$ & Metalinguistic and Recast & Phonological error \\
\hline & Teacher's Practice & Teacher & $\begin{array}{l}\text { Immediate } \\
\text { feedback }\end{array}$ & Metalinguistic & Morphosyntactic errors \\
\hline \multirow[t]{2}{*}{2} & Teacher's Belief & Teacher & $\begin{array}{l}\text { Immediate } \\
\text { feedback }\end{array}$ & Recast & $\begin{array}{l}\text { Phonological \& } \\
\text { Morphosyntactic errors }\end{array}$ \\
\hline & Teacher's Practice & Teacher & $\begin{array}{l}\text { Immediate } \\
\text { feedback }\end{array}$ & Metalinguistic & Phonological errors \\
\hline \multirow[t]{2}{*}{3} & Teacher's Belief & Teacher & $\begin{array}{l}\text { Immediate } \\
\text { feedback }\end{array}$ & Meta-linguistic & Morphosyntactic errors \\
\hline & Teacher's Practice & Teacher & $\begin{array}{l}\text { Delayed } \\
\text { feedback }\end{array}$ & Explicit correction and Meta-linguistic & Morphosyntactic errors \\
\hline \multirow[t]{2}{*}{4} & Teacher's Belief & Teacher & $\begin{array}{l}\text { Delayed } \\
\text { feedback }\end{array}$ & $\begin{array}{l}\text { Explicit correction Meta-linguistic and } \\
\text { Clarification request }\end{array}$ & Semantic and pragmatic error \\
\hline & Teacher's Practice & Teacher & $\begin{array}{l}\text { Delayed } \\
\text { feedback }\end{array}$ & Meta-linguistic and Recast & Morphosyntactic errors \\
\hline \multirow[t]{2}{*}{5} & Teacher's Belief & Teacher & $\begin{array}{l}\text { Delayed } \\
\text { feedback }\end{array}$ & Meta-linguistic & Phonological error \\
\hline & Teacher's Practice & Teacher & $\begin{array}{l}\text { Immediate } \\
\text { feedback }\end{array}$ & Explicit correction and Meta-linguistic & Morphosyntactic errors \\
\hline \multirow[t]{2}{*}{6} & Teacher's Belief & $\begin{array}{c}\text { Teacher \& } \\
\text { Student }\end{array}$ & $\begin{array}{l}\text { Delayed } \\
\text { feedback }\end{array}$ & Meta-linguistic and Recast & Semantic and pragmatic error \\
\hline & Teacher's Practice & Teacher & $\begin{array}{l}\text { Immediate } \\
\text { feedback }\end{array}$ & Meta-linguistic and Recast & Morphosyntactic errors \\
\hline \multirow[t]{2}{*}{7} & Teacher's Belief & Teacher & $\begin{array}{l}\text { Immediate } \\
\text { feedback }\end{array}$ & Recast \& Clarification request & $\begin{array}{l}\text { Phonological \& } \\
\text { Morphosyntactic errors }\end{array}$ \\
\hline & Teacher's Practice & Teacher & $\begin{array}{l}\text { Immediate } \\
\text { feedback }\end{array}$ & Explicit correction and Meta-linguistic & Morphosyntactic errors \\
\hline \multirow[t]{2}{*}{8} & Teacher's Belief & Teacher & $\begin{array}{l}\text { Immediate } \\
\text { feedback }\end{array}$ & Recast \& Clarification request & Morphosyntactic errors \\
\hline & Teacher's Practice & Teacher & $\begin{array}{l}\text { Immediate } \\
\text { feedback }\end{array}$ & Meta-linguistic & Morphosyntactic errors \\
\hline
\end{tabular}

\section{Discussion}

\subsection{Who Should Provide Feedback?}

In terms of who should give OCF, 6 out of the 8 participants, stated beliefs about OCF that were identical with their classroom practices. Their responses show preference that a teacher should give OCF. Two participants showed inconsistency between his stated beliefs and classroom practice. His response outlined the preference 
that teachers and students should give OCF; a point that contradicts with his tendency to give feedback himself in practice. Accordingly, hypothesis no.1 which states that "there is inconsistency between the Kurdish EFL teachers' beliefs and classroom practices concerning who should provide OCF" is accepted.

\subsection{Feedback Timing}

Regarding the timing to give OCF, the findings suggest consistency between the stated beliefs and classroom practices regarding the timing of OCF of four participants (participants 2, 4, 7 and 8). Participants 2, 7 and 8 showed preference for immediate feedback and consequently demonstrated it practically in their classes, while participant 4 preferred delayed feedback and proved that in practice as well. This is in line with the consistency between teachers' beliefs and classroom practices arrived at by Ölmezer-Öztürk (2016). This is on one hand. On the other hand, the other four participants, 1, 3,5, and 6 showed inconsistency between their stated beliefs and observed practices. Accordingly, hypothesis no.2 which states that "there is inconsistency between the Kurdish EFL teachers' beliefs and classroom practices concerning the timing of OCF" is accepted.

\subsection{Type of Corrective Feedback}

A total of 8 participants were observed to practice metalinguistic feedback. On the other hand, the results showed that 5 out of the 8 participants showed preference to use metalinguistic feedback. While participants 2,7 and 8 showed inconsistency as far as their stated beliefs and classroom practices were concerned. This is in line with the results arrived at by (Roothooft, 2014) and (Basturkmen, Loewen, \& Ellis, 2004). Participant 6 showed full consistency between his stated beliefs and classroom practices by giving the Meta-linguistic and Recast type of feedback; a point that proved via practical observation of his classroom practices. Accordingly, hypothesis no.3 which states that "there is inconsistency between the Kurdish EFL teachers' beliefs and classroom practices concerning the type of OCF provided" is accepted.

\subsection{Errors to Correct}

Regarding which errors to correct, only participants 3 and 8 showed consistency between his stated beliefs and classroom practice by showing preference to correct the morphosyntactic errors. The other six participants, namely 1,2, 4, 5, 6, and 7 showed inconsistency between their stated beliefs and practices regarding which error to correct. Accordingly, hypothesis no.4 which states that "The present study hypothesized that there is inconsistency between the Kurdish EFL teachers' beliefs and classroom practices concerning the types of errors to correct" is accepted.

\section{Conclusion}

The current study has investigated the beliefs and classroom practices of 8 Kurdish EFL teachers regarding certain points relevant to the provision of OCF. In general, there has been consistency to a large extent regarding teachers' beliefs and classroom practices on "who should provide feedback" as the sample of teachers has almost unanimously agreed upon that the teacher rather than the student should provide feedback. As for the "the timing to provide OCF", i.e. immediate or delayed, half of participants showed consistency between their stated beliefs and actual practice in classrooms. Furthermore, the participants preferred immediate feedback more than delayed feedback. Though discrepancy was noticed between beliefs and practice with regard to how to provide OCF, teachers have demonstrated noticeable tendency to provide metalinguistic feedback more than the others types of OCF. Finally, there was a considerable difference with regard to the sample's beliefs and classroom practices concerning "the types of errors to correct". To sum up, (Kamiya, 2016, p. 13) states that the mismatch between teachers' beliefs and classroom practices is but a natural phenomenon that may be viewed as a process during professional development; as such, it can be considered as an opportunity rather than a fault or a shortcoming.

The study is limited to 8 EFL teachers working at state high schools in Iraqi Kurdistan Region on spoken errors of learners. It might be extended to include a larger number of teachers working at primary or secondary schools located in different countries.

\section{References}

Alzeebaree, Y, T. (2017). Research into the Development of Interlanguage Pragmatic Competence of EFL Learners in Northern Iraq. Cyprus International University, Nicosia, North Cyprus.

Basturkmen, H., Loewen, S., \& Ellis, R. (2004). Teachers' stated beliefs about incidental focus on form and their classroom practices. Applied linguistics, 25(2), 243-272. https://doi.org/10.1093/applin/25.2.243

Chandler, J. (2003). The efficacy of various kinds of error feedback for improvement in the accuracy and fluency of L2 student writing. Journal of Second Language Writing, 12(3), 267-296. https://doi.org/10.1016/S1060-3743(03)00038-9 
Cornillie, F., Clarebout, G., \& Desmet, P. (2012). The role of feedback in foreign language learning through digital role-playing games. Procedia - Social and Behavioral Sciences Procedia - Social and Behavioral Sciences, 34(4), 49-53. https://doi.org/10.1016/j.sbspro.2012.02.011

Ellis, R. (2009). A typology of written corrective feedback types. ELT Journal, 63(2), 97-107. https://doi.org/10.1093/elt/ccn023

Ellis, R. (2010). Epilogue: A framework for investigating oral and written corrective feedback. Studies in Second Language Acquisition, 32(2), 335-349. https://doi.org/10.1017/S0272263109990544

Ferris, D. R., \& Helt, M. (2000). Was Truscott right? New evidence on the effects of error correction in L2 writing classes. Paper presented at the American Association of Applied Linguistics Conference. Vancouver, BC, March, 11-14.

Frantzen, D. (1995). The effects of grammar supplementation on written accuract in an intermediate Spanish $\begin{array}{lllll}\text { content } & \text { course. Modern }\end{array}$ https://doi.org/10.1111/j.1540-4781.1995.tb01108.x

Gass, S. (1997). Input, interaction, and the second language learner. Mahwah, N.J.: Lawrence Erlbaum.

Hattie, J., \& Timperley, H. (2007). The power of feedback. Review of educational research, 77(1), 81-112. https://doi.org/10.3102/003465430298487

Hernández Méndez, E., Cruz, R., \& del Rosario, M. (2012). Teachers' Perceptions About Oral Corrective Feedback and Their Practice in EFL Classrooms. Profile Issues in TeachersProfessional Development, 14(2), 63-75.

Hyland, K. (1990). Providing productive feedback. ELT Journal, 44(4), 279-285. https://doi.org/10.1093/elt/44.4.279

Kamiya, N. (2016). The relationship between stated beliefs and classroom practices of oral corrective feedback. Innovation in Language Learning and Teaching, 10(3), 206-219. https://doi.org/10.1080/17501229.2014.939656

Lalande, J. F. (1982). Reducing Composition Errors: An Experiment. The Modern Language Journal, 66(2). https://doi.org/10.1111/j.1540-4781.1982.tb06973.x

Li, S. (2010). The effectiveness of corrective feedback in SLA: A meta-analysis. Language Learning, 60(2), 309-365. https://doi.org/10.1111/j.1467-9922.2010.00561.x

Li, S. (2014). Oral corrective feedback. ELT Journal, 68(2), 196-198. https://doi.org/10.1093/elt/cct076

Lightbown, P. M., \& Spada, N. (1990). Focus-on-Form and Corrective Feedback in Communicative Language Teaching: Effects on Second Language Learning. Studies in Second Language Acquisition, 12(4), 429-448. https://oi.org/10.1017/S0272263100009517

Long, M. H. (2006). Problems in Second Language Acquisition. Mahwah, NJ: Lawrence Erlbaun Associates.

Lyster, R. (2015). The Relative Effectiveness of Corrective Feedback in Classroom Interaction. In N. Markee (Ed.), The handbook of classroom discourse and interaction (pp. 213-228). Oxford: Wiley-Blackwell. https://doi.org/10.1002/9781118531242.ch13

Lyster, R., \& Saito, K. (2010). Oral Feedback in Classroom SLA: A Meta-Analysis. Studies in Second Language Acquisition, 32(2), 265-302. https://doi.org/10.1017/S0272263109990520

Nassaji, H., \& Kartchava, E. (2017). Corrective feedback in second language teaching and learning : research, theory, applications, implications. New York; London: Routledge.

Ölmezer-Öztürk, E. (2016). Beliefs and practices of Turkish EFL teachers regarding oral corrective feedback: a small-scale classroom research study. The Language Learning Journal, 1-10. https://doi.org/10.1080/09571736.2016.1263360

Robb, T., Ross, S., \& Shortreed, I. (1986). Salience of feedback on error and its effect on EFL writing quality. TESOL Quarterly, 20, 83-93. https://doi.org/10.2307/3586390

Roothooft, H. (2014). The relationship between adult EFL teachers' oral feedback practices and their beliefs. System, 46, 65-79. https://doi.org/10.1016/j.system.2014.07.012

Saville-Troike, M. (2007). Introducing second language acquisition. Cambridge: Cambridge University Press.

Varnosfadrani, A. D. (2006). A comparison of the effect of implicit/explicit and immediate/delayed corrective 
feedback on learners' performance in tailor-made test. Unpublished $\mathrm{PhD}$ dissertation. University of Auckland.

Voerman, L., Meijer, P. C., Korthagen, F. A. J., \& Simons, R. J. (2012). Types and frequencies of feedback interventions in classroom interaction in secondary education. Teaching and Teacher Education, 28(8), 1107-1115. https://doi.org/10.1016/j.tate.2012.06.006

\section{Copyrights}

Copyright for this article is retained by the author, with first publication rights granted to the journal.

This is an open-access article distributed under the terms and conditions of the Creative Commons Attribution license (http://creativecommons.org/licenses/by/4.0/). 